\title{
Exploring Etymology and Language Contact Through Digital Lexicographical Encoding: The Dictionary of Loanwords in the Midrash Genesis Rabbah (DLGenR)
}

\author{
Christina Katsikadeli \\ ACDH-CH, Austrian Academy of Sciences \\ Christina.Katsikadeli@oeaw.ac.at
}

\author{
Thomas Klampfl \\ ACDH-CH, Austrian Academy of Sciences \\ Thomas.Klampfl@oeaw.ac.at
}

\author{
Vladislav Slepoy \\ University of Salzburg \\ Vladislav.Slepoy@sbg.ac.at
}

\begin{abstract}
This paper aims at demonstrating the advantages of the research on predominantly Greek loanwords in the Rabbinic literature, as employed in the Digital Dictionary of Loanwords in the Midrash Genesis Rabbah (DLGenR). This line of research can contribute to further elucidating a number of issues concerning language usage in the cultural context of Graeco-Roman Palestine and relevant lexicographical practice to the benefit not only of Rabbinic studies but also of linguistics and historical disciplines. In particular, the present survey explores the etymological criteria which should be fulfilled by a historical dictionary specialized in borrowings and attempts to provide a maximal inventory of their deep encoding in electronic dictionaries (according to TEI Lex-0).
\end{abstract}

Keywords: Jewish Palestinian Aramaic, Greek, linguistic borrowing, eLexicography, etymology, TEI

\section{Introduction: sociolinguistic setting}

As far as the linguistic situation in the Eastern provinces of the Roman Empire is concerned, Greek was spoken by people whose native languages were Hebrew, Aramaic (and Phoenician). Judging on the basis of historical, archaeological and philological material, the social and economic conditions prevailing in the cities in Syria-Palestine would resemble those in Egypt, thus displaying a "stable bilingualism" (cf. Clackson 2012: 47ff.), but we do not have many details at our disposal due to the nature of the evidence, which consists of learned texts and inscriptions (there are virtually no private letters and business documents, which are so common in the Egyptian papyri). Although we do not know the exact time when the Jewish communities started to use the Greek language for the first time, there exists ample evidence for the fact that Greek was well embedded at several social levels, although further details still remain vague and unclear. According to Smelik (2012: 5), "[f]or the majority of Palestinian Jews Greek was probably not the native language but an acquired vernacular, yet it is difficult to determine the extent of the knowledge and use of Greek among the Jewish population, apart from those who were directly involved with the Roman administration and therefore required to speak Greek."

The language contact between Palestinian Aramaic and Greek resulted into the largest set of loanwords that amount to over two thousand items in the entire Hebrew/Aramaic lexicon, i.e. in post-Biblical Hebrew (Mishnaic Hebrew), Jewish Palestinian Aramaic and Jewish Babylonian Aramaic.

In the following passages, we deal with some examples of Greek loanwords occurring in an important text from Judaism's classical period, which is the earliest Rabbinic commentary on the Book of Genesis, compiled during the early $5^{\text {th }} \mathrm{c}$. CE in Roman Palestine. Genesis Rabbah (GenR) is rich in foreign words, especially Greek (about 400 types), i.e in this text we encounter about $1 / 3$ of the Greek lexemes of the entire Rabbinic literature. The Latin borrowings, in general, entered Jewish Aramaic via Greek (hence: "Latinate"). A further important fact with respect to the main language of the GenR 
corpus is that we mainly deal with the Jewish Palestinian variety of Aramaic (JPA) and not with postBiblical Hebrew, although Hebrew forms also encounter.

For post-Classical Greek, however, our secondary evidence consists of Aramaic and Hebrew transliterations of Greek words in the Rabbinic literature (Mishnah, Targums, Talmuds). Scholars from the domains of historical linguistics and classics interested in Greek loanwords, which occur in these Semitic dialects, are confronted with the fact that apart from the monumental work by Krauss from the end of the $19^{\text {th }}$ century, one still has to rely on the later important but not exhaustive contributions by Lieberman and Sperber from the second half of the $20^{\text {th }}$ century (Sperber 1984, 1986, 2012). To put it in a nutshell, there exists no up-to-date dictionary or "Grammar" for the Greek loanwords in this vast literary tradition. Only in the last decade, it has become possible to consult further important, pioneering publications and tools concerning the linguistic analysis of Greek loanwords in Rabbinic texts ${ }^{1}$. Nevertheless, a considerable number of existing entries need to be supplemented and many etymologies must be revised in the light of more recent research and methodology.

\section{Compiling the entry}

The examples we present in the following passages display findings from the project "Dictionary of Loanwords in Genesis Rabbah" (funded by the Austrian Science Fund, FWF at the Center for Jewish Cultural History, University of Salzburg and at the Austrian Academy of Sciences, Vienna for the period 2018-2021). The project's objective consists in the compilation of a dictionary both in digital (open access) and in book format. This research aims at providing an efficient tool for further cultural and linguistic analysis, which will serve not only the needs of the respective midrash and the Rabbinic studies, but also the promotion of the investigation on the interaction between Jewish literary tradition with other cultures in Late Antiquity. Further, the project will also contribute to diachronic Greek linguistics and lexicography. One important outcome of this project will be an up-to-date overview on the adaptation phenomena of Greek borrowings in Aramaic, since the main references on this subject, still, are the few examples in Dalman's Grammar from the year 1905. The presentation of the data in the present paper can be broken down as follows: the first part mainly focuses on hapax legomena and problematic cases of (alleged) Greek loanwords, by examining each attestation of the respective lexeme in its specific context and by offering an up-to-date linguistic analysis, pertaining to their origin, their morphophonology as well as to their fine-grained semantics, in other words, to their "etymological treatment" Furthermore, the investigation pursues - where possible - comparisons with the Greek loaned vocabulary in other linguistic traditions of the Eastern Mediterranean. The second part comprises the encoding of these examples according to the specifications of the baseline encoding TEI Lex- 0 for electronic dictionaries. ${ }^{2}$

\subsection{General outlines}

On the pre-lexicographical level the following decisions have been made for the DLGenR:

- The project consists of a compilation of a digital dictionary of loanwords in GenR, from which the lemmas will be published online in an Open Access format.

- The target language of the dictionary is English

- The lexicographic editor is the VLE ("Viennese Lexicographic Editor", in cooperation with the Austrian Center for Digital humanities \& Cultural Heritage (ACDH-CH) at the Austrian Academy of Sciences (ÖAW) ${ }^{3}$

\footnotetext{
${ }^{1}$ The most extensive studies are: Heijmans' PhD thesis on Greek and Latin loanwords in Mishnaic Hebrew. Lexicon and phonology (2013) and the work by Shoval-Dudai on Classical and Post-Biblical Hebrew (s. bibliography).

${ }^{2} \mathrm{https}$ ///dariah-eric.github.io/lexicalresources/pages/TEILex0/TEILex0.html

${ }^{3}$ See also Moerth \& Schopper in this volume.
} 
- After completing the digital edition of the lemmas, the team also plans a publication in book format, where the lemmas will be presented in an onomasiological order, i.e. in "word fields" along with other socio-cultural comments and remarks in order to highlight the linguistic and cultural interaction in GenR. This investigation will also employ digital tools for the study of lexical semantics and sociolinguistic analyses as well as an alignment with other lexicographical resources already available. The macrostructure of the dictionary consists of the following features:

- The word list comprises all the Greek loanwords in GenR (or the words which have been identified as "Greek") in the respective literature, starting with the indices in the Theodor-Albeck edition and the entries in Sokoloff's and Sperber's dictionaries; problematic classifications are also included, accompanied by the respective information, cf. also Hirschman 2010.

- The corpus: Since we do not have a new critical edition of GenR at our disposal, the team started the investigation of each lemma according to the Theodor-Albeck edition (MsBritMus), despite its shortcomings, but alongside the permanent consultation of the Ms Vat. 30 and Ms Vat. 60 (online available) and of the respective Genizah fragments.

It is a commonplace in Rabbinic studies that the nature of the texts, the manuscript editions and the writing system do not facilitate the tracing of loanwords not only in GenR but also in the Rabbinic literature in general. The phonology of loanwords in Mishnaic Hebrew and Aramaic is very problematic per se. Neither the spelling of the loanwords nor their vocalization (where extant) are consistent. Unlike Biblical Hebrew, the Rabbinic literature never obtained a canonical form and the texts vary with each manuscript. It should be emphasized that many equivalents for one lexeme are possible.

\section{Checking etymologies I: methodological issues}

Samuel Krauss (1866-1948) and his contemporaries have often been criticized that their proposals on Greek loanwords in disregarded linguistic methodology. This line of reasoning was in fact anachronistic, since this work was based on the textual and linguistic information pools of the that time, which date back many years before the first "scientific" etymological dictionary of Ancient Greek by Hjalmar Frisk (Heidelberg 1960-1972). Quite on the contrary, Krauss' insightful proposals show a remarkable knowledge of the Greek language alongside the consideration of post-Classical, Middle and Modern Greek lexical forms and/or semantics, something that many classicists and historical linguists have failed - or still fail - to recognize. Needless to say, there is no comparison between the lexicography at the end of the $19^{\text {th }} \mathrm{c}$. and today's state of the art, where one can draw upon a rich lexicographical tradition based on scientific criteria, linguistic theory and tested methodologies, which, in turn, can be applied to the borrowed lexicon in post-Classical Hebrew and Aramaic.

Despite the fact that the Rabbinic material is of vast dimensions, significant progress has been made in the past decades resulting in considerable correction and supplementation of the older dictionaries: new texts have been published and old familiar ones have reappeared in critical editions. The manuscript material has now become readily available for the verification of readings, and as a result a number of non-existent words have been corrected. As far as the Greek corpora are concerned, although we have made considerable progress in the study of post-Classical Greek, our knowledge on the variety of Greek spoken in Palestine during the post-Classical period is still based - in the first place - on the studies in New Testament Greek, which, along with the translation of the Septuagint, the works by Philo and Flavius Josephus as well as the anonymous Old Testament apocrypha and pseudepigrapha, are the principal literary works in Hellenistic Koine. ${ }^{4}$ Compared to its counterpart in Egypt, the Hellenistic epigraphic material from Syria-Palestine is not that ample, the content of the inscriptions is less variegated, and in most cases they were written by commoners. In contrast to the Old and the New

\footnotetext{
${ }^{4}$ Including extra-canonical works such as 4 Ezra and 2 Baruch, and the no longer extant works of Justus of Tiberias.
} 
Testament as well as to Josephus Flavius, these inscriptions lack the presence of structural Semitisms. On the downside, in the last years major important projects concerning Byzantine Greek have come to completion, the LBG (Lexikon zur Byzantinischen Gräzität) ${ }^{5}$ being the most important one for the DLGenR compilation.

Although several Greek loanwords in the Jewish literary tradition might seem straightforward, the bulk of these lexical items involve the examination of whether this specific word is Greek, and if this is the case, which one of several possibilities could be the most - scientifically speaking appropriate, not only according to the semantics of the context, but also on the basis of other relevant linguistic criteria. Thus, for every single entry, one has to start anew the application of an entire range of phonological and morphological possibilities alongside semantics. As a consequence, the dictionary type of the DLGenR shifts from a lexicon that initially focuses on the word-history (histoire des mots) of the loanwords in a certain linguistic variety to an etymological one, which explores the history of origin (histoire des origins). In order to capture the range of the various decisions we had to make for the DLGenR entries, in what follows, we present a set of criteria that an etymological survey should fulfil, in accordance with the maximal model proposed by Hoffmann and Tichy (1980): this "check list" encompasses 6 major groups divided into 39 categories (often with further subdivisions) and has been extended and adjusted to the needs of DLGenR, in agreement with current advances in contact linguistics and the study of borrowings. Thus, before we deal with the tracing of the word meaning and the adaptation level of a loanword, we reconsider even "more basic" issues for every entry and start with the categorization related to the "occurrence" of a lexeme, as proposed in the aforementioned overview by Hoffmann \& Tichy (1980: 47-52)

\subsection{Linguistic "reality"}

The progress in Rabbinic studies and Greek linguistics we briefly summarized above enables us to obtain correct readings and etymologies in the light of more recent research and methodology. The lexicon entries should comply with the criteria of modern linguistics by not only expelling ghost-words but also by replacing various "adventurous", "impressionistic" explanations, thus restoring the "linguistic reality" of an occurrence or the "credibility" of a certain proposal. Among many examples, here, we just limit ourselves to two kinds of "shortcomings" in the older dictionaries: a) the lack of information whether the Greek corresponding form is actually reconstructed or attested in Greek, cf. a.o. the mention of a reconstructed form $* \delta \rho \circ \mu \omega \lambda \eta \varsigma$ 'runner' without the appropriate indication. This fact might lead the reader to the false assumption that this compound actually occurs in Greek sources ${ }^{6}$; or b) the etymological linkage to existing Greek words without taking into consideration the relevant historical evidence: e.g. <'lsys $>/$ alsis/, <'lsws $>/$ alsos/ noun m., probably for 'grove (of Tiberias) ' $\sim$ Gr. $\alpha 2 \lambda \sigma o s$ in GenR 34,15 (I 327: 4); 96 [acc. to Vat 1] (III 1240: 8). Although the readings must remain ambiguous or uncertain for this lexeme, it is important to rule out anachronistic proposals from the dictionaries, as in the case of 'H $\lambda \tilde{\sigma} \sigma i v v$ ( $\pi \varepsilon \delta$ íov): the later well-known Early Modern designation 'H $\lambda \dot{\sigma} \sigma i o v$ (cf. French Champs-Élysées) pertaining to 'gardens, parks' or 'boulevards' has not been secured for the Roman times; but even if this might have been the case, the etymologist has to provide further evidence for similar application of such a highly poetic or learned style of Greek to other place names in Palestine of that time. The latter example is also directly related to the next set of criteria:

\footnotetext{
${ }^{5}$ http://stephanus.tlg.uci.edu/lbg/\#eid=1

${ }^{6}$ For further discussion, see Katsikadeli \& Slepoy 2020. 


\subsection{Chronological and areal distinctions of the borrowings and their attestation frequency}

As far as the regional and chronological criteria are concerned, the existing dictionaries and glossaries have been treating the Greek loanwords in Hebrew/Aramaic very poorly: their entries were restricted to the mention of an existing or somehow correlated Greek "type", which can be found in the major Greek and Latin lexicographical works, without commenting on its "age", region or frequency of occurrence. If we take a closer look at our material, we will notice that even in "clear" cases of Greek loanwords one has to consider the date and region of the attested Greek word. For instance, the Aramaic form <mylnyn> /melnin/ 'ink', which could be easily explained with Gr. $\mu \varepsilon \dot{\lambda} \alpha \nu$ or $\mu \varepsilon \lambda \alpha$ viov with the same meaning (Krauss, LW II 336b), occurs only in the following passage from GenR:

(1) GenR 1,4 (I 6: 15)

"A king was married to a certain lady, and had no son by her. On one occasion the king was found going through the marketplace and giving orders: 'Take this ink, inkwell and pen for my son,' at which people remarked: 'He has no son: what does he want with ink and pen? Strange indeed!'”

(Freedman / Simon I 7)

Although the semantic connection with the Greek word for 'black; ink' is obvious, the precise morphological assignment is far from clear. Here, three possibilities should be taken under consideration: a) The most frequent Greek lexeme for the designation of the color 'black' would be $\mu \varepsilon \dot{\varepsilon} \lambda \alpha v$. This, in turn, would suggest that in GenR we deal with the Aramaic plural form -in, /melnin/, which could be explained as a "collective" plural of a mass noun (although in such cases the expected plural forms display the feminine ending -ot); b) A feminine Gr. noun $\mu \varepsilon \lambda$ ávๆ 'ink' is also attested in texts from Palestine around the $5^{\text {th }}$ c.CE, but here again we would expect an Aramaic counterpart $*<\mathrm{m}(\mathrm{y}) \operatorname{lny}>$ or $*<\mathrm{m}(\mathrm{y}) \operatorname{lnh}>$ and not $<$ mylnin $>\mathrm{c}$ ) For Aramaic /melnin/, the phonologically appropriate source form - from what we already know about the adaptation of Greek into Aramaic - would be rather $\mu \varepsilon \lambda \alpha$ óviov. And indeed, we find this Greek form in this same region and in this same period; c) in addition, a form $\mu \varepsilon \lambda \alpha$ áviv, which corresponds exactly to /melnin/ as a possible source lexeme is also attested in Middle Greek sources (cf. LBG s.v.). According to the above outline, we should consider only the latter two forms, thus $\mu \varepsilon \lambda \alpha v^{\prime} \mathrm{l}(\mathrm{o}) \nu$ and not $\mu \varepsilon \dot{\lambda} \alpha \alpha v$, as the corresponding Greek form(s) for this hapax legomenon. We move on to another Hellenistic Greek word for 'black', namely $\mu \alpha \tilde{v} \rho \varsigma_{\zeta}$, $\mu \alpha v \rho o ́ \varsigma$ that has been adapted by speakers of JPA, cf. the following example (2), where the loanword is attested in a syntagmatic opposition with its antonymic lexeme ó $\sigma \pi \rho \varsigma_{\varsigma}$ '(silver)white', a word of Latin origin initially used for describing skin.

(2) GenR 7,4 [I 53: 4]

"R. Yeremiyah said: [R.] Kahana' asked R. Shim 'on b. Laqish: 'What if one crosses different sea species?' 'In their case, too After their kind is written,' he answered. With this the son of Laqish spread his net over [R.] Kahana'. Kahana', however, refuted him: 'Yet in the case of fish, too, After their kind is written.' With this Kahana' spread his net over the son of Laqish. Now how is it to be explained? Said R. [Yonah]: I can apply it [sc. 'after their kind'] to the prohibition of driving: he brings two fish, one white and the other black, ties them with a reed rope and pulls them, for we learned: You may not plough with, pull, or drive them."

(Freedman / Simon I 51-52)

While $\mu \alpha \tilde{v} \rho \varsigma_{\varsigma}$ should be considered a "well-established" item of the post-Classical Greek lexicon and is actually attested in the Greek sources from Roman Caesarea, the Aramaic form <'sprwn $>$ /asperon/, adj. 'white' Gr. ö $\sigma \pi \rho o v$, is used in GenR as a noun referring to a kind of fish and seems to have entered JPA very early: the "epichoric" Greek corpora display the emergence of ö $\sigma \pi \rho \circ \varsigma$ as an interchangeable counterpart for the archaic $\lambda \varepsilon v \kappa o ́ s ~ m u c h ~ l a t e r 7$. But if we take a closer look at the geographical/chronological Map 1 below, we will also find öб $\pi \rho \varsigma_{\text {in }}$ a Greek text from the same period

\footnotetext{
${ }^{7}$ For the development and distribution of denotations for 'white' leukos and aspros in the diachrony of Greek, see Fliatouras \& Sampanis in this volume.
} 
and region of the redaction of GenR $\left(5^{\text {th }}\right.$ c.CE). Thus, both color terms are plausible loans from the Hellenistic varieties used in late antiquity and early Byzantine times in that area.

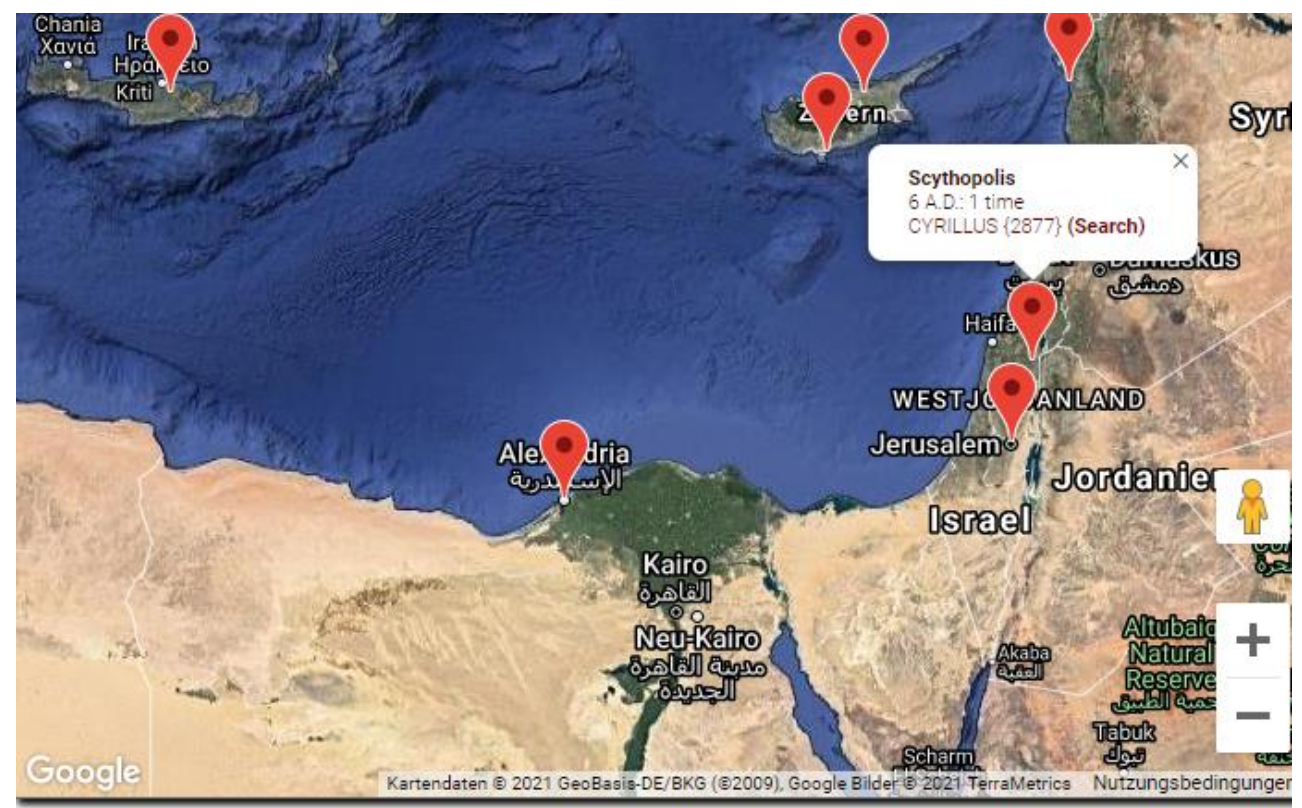

Map 1: Geographical distribution of the texts containing $\alpha$ $\sigma \pi \rho \varsigma^{\prime}$ 'white' (TLG)

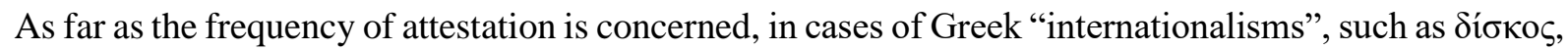
this information seems redundant, but other instances are noteworthy. For instance, some Greek terms "shared" by Greek and Aramaic sources during certain periods: GenR encompasses several lexemes, which are rare in Hellenistic and Byzantine texts, e.g. <prqty' $\mathrm{h}>$ /prakțeiah/ noun f. 'official positions' $\sim$ Gr. $\pi \rho \alpha \kappa \tau \varepsilon i \alpha^{8}$ pl. < Gr. $\pi \rho \alpha \kappa \tau \varepsilon i ̃ o v$, which is attested only in inscriptions and in Gregorius' Vita J.Chrysostomii $\left(17.34 ; 7^{\text {th }}\right.$ c. CE). Another case of a rare lexeme refers to the Aramaic form $<$ 'prks $>$

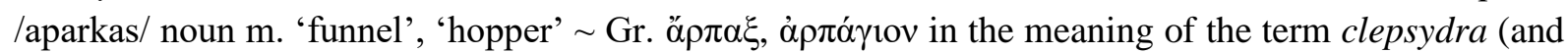
not of 'raptor' or any of this words' other meanings in Greek) ${ }^{9}$, as the context in GenR 4,4 suggests. Connections of the masculine form < prks $>$ with a clepsydra can be found both in the neuter noun

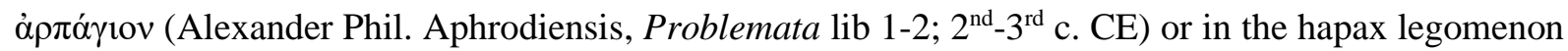
compound $\dot{v} \delta \rho \alpha \dot{\rho} \pi \alpha \xi$ in Simplicius $\left(6^{\text {th }}\right.$ c. CE). It is noteworthy that the mentions of the $\dot{\alpha} \rho \pi \alpha \gamma_{10 v}$ are more frequent in Aramaic than in Greek (see also Map 2), and the context indicates that the Rabbinic authors take the general knowledge of the semantics of this word for granted. In any case, it is always important to consult up-to date editions of Hellenistic and Early Byzantine sources (and the later potential survivors of the Greek lexemes in Medieval and Modern Greek) in addition to the Classical and patristic sources.

Another neglected issue concerning the areal distribution is the Greek loaned vocabulary exclusively

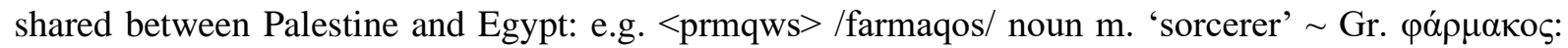
This agentive noun is attested only in Rabbinic texts, the LXX and Coptic sources (фармaroc) ${ }^{10}$. These cases might be useful for tracing the distribution and the regional character of certain lexemes shared by the Ptolemaic and Syro-Palestinian Koine. In addition, it is equally important to examine the exact compatibility of areal, semantic and contextual/historical conditions, when proposing the appropriate

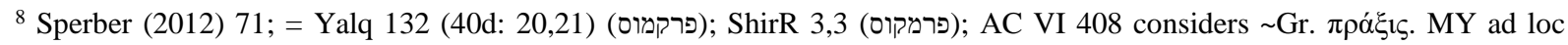

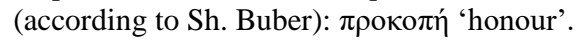

${ }^{9}$ Cf. a.o. 'a kind of a wolf' or 'flesh-hook' (LSJ s.v.).

${ }^{10}$ To be distinguished from $\varphi \alpha \rho \mu \alpha \kappa o ́ \varsigma$ 'one sacrificed or executed as an atonement or purification for others, scapegoat' (cf. LSJ s.v.)
} 
corresponding Greek form in Aramaic. Especially the most obvious cases prove to be a tricky matter, e.g. the word $\delta i \varphi \theta \varepsilon \dot{\varepsilon} \rho \alpha$ : In the Rabbinic literature we deal with specialized semantics of this lexeme, namely 'record book', beside the primary meaning 'hide (for writing)', which is attested in the Mishnah (cf. e.g. mMeg 2,2). The denotation 'record book' is in fact rare in the Greek corpus and interestingly, it is witnessed as the description of Persian 'royal' record books (Ctes. ap. D.S.2.32). In addition, it is worth mentioning that $\delta i \varphi \theta \varepsilon \dot{\varepsilon} \alpha$ evolves to a Wanderwort, which starts from the Aramaic loanword and finally reaches Modern Greek via Arabic (دفتر) and Turkish (defter) as a re-borrowing with a narrowed, specialized meaning: $\tau \varepsilon \varphi \tau \varepsilon \dot{\rho} \rho \mathrm{l}$ 'record book'. Thus, the attestations of this word in Palestinian Aramaic already witness this Oriental meaning specialization.

Finally, the relationship between the Greek loanwords and their Greek counterparts as well as their "region and time" distinction is just as important as their difference in usage within one single text, or between the various Jewish texts and genres. A representative example for this variation is the use of the more archaic Greek color term $\lambda \varepsilon v \kappa o ́ \varsigma$ in a parallel passage of GenR 7,4 (in (2) above) from the Palestinian Talmud, instead of the post-Classical term ó $\sigma \pi \rho \varsigma^{11}$.

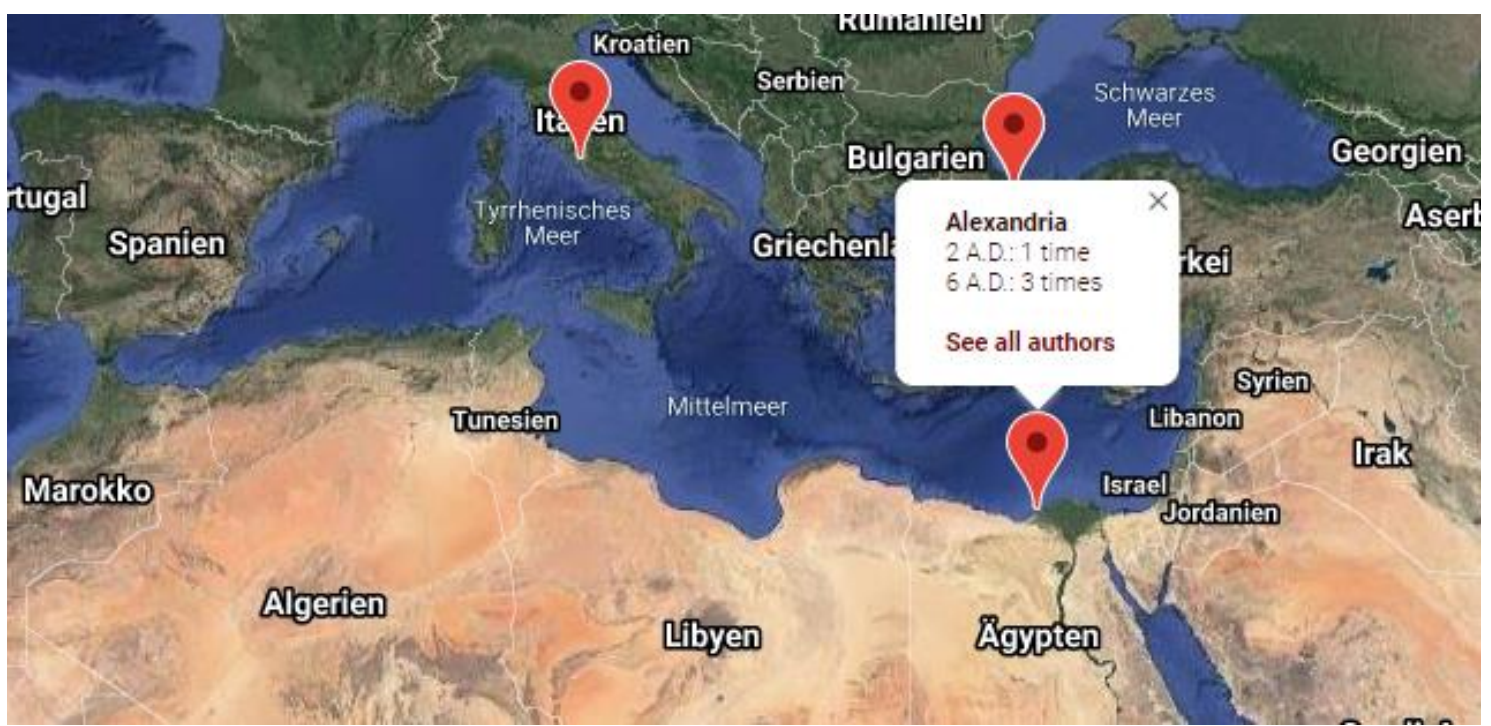

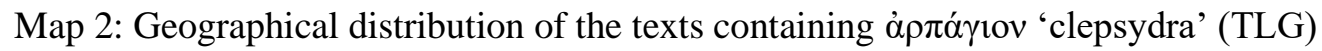

\subsection{Linguistic authenticity}

Compared to the loanwords attested in other linguistic traditions of the Eastern Mediterranean, the inventory of Greek loanwords in Jewish Aramaic proves to be the most "restricted" one, whereas the Graeco-Coptic material from Hellenistic Egypt concerns "heavy borrowing". Furthermore, the SyriacAramaic $^{12}$ situation should be placed somewhere between this Egyptian-Palestinian "continuum". Therefore, despite the fact that the collection and explanation of Greek loanwords goes back to a long tradition, the evidence from the Rabbinic literature has been considered a "manageable" group of isolated lexical items, which mainly involve the so-called "material" and not the "pattern" borrowing"13,

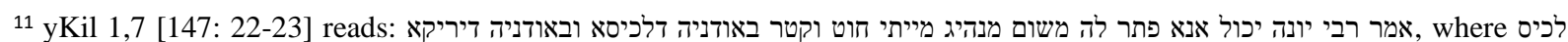
<lkys> /lakis/ can be explained as Gr. $\lambda \varepsilon v \kappa o ́ \varsigma$ “white” (while ירוק is Hebr./Aram. "green”, "yellow”). However, Löw (in Krauss,

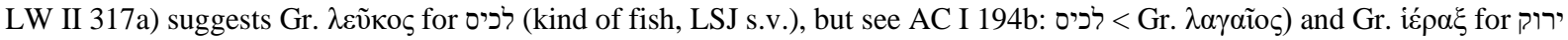
(kind of fish, LSJ s.v.).

${ }^{12}$ For recent findings see Butts (2016).

${ }^{13}$ As described by Haspelmath (2009: 38-39): "A basic distinction that must be made is that between material borrowing and structural borrowing [or matter borrowing and pattern borrowing, according to Matras \& Sakel 2007]. Material borrowing refers to borrowing of sound-meaning pairs (generally lexemes, or more precisely lexeme stems, but sometimes refers to the
} 
as in the case of Coptic. ${ }^{14}$ The linguistic impact of Greek in Roman Palestine never resulted into "advanced" borrowing phenomena, such as word order or case-marking patterns; nevertheless, a more meticulous investigation allows us to discover deeper and more complex mechanisms of borrowing and a higher level of linguistic competence of Greek among the Rabbinic authors as it is usually assumed in the respective scholarship. We have ample evidence at our disposal that the code-switching hierarchy for Greek loanwords in GenR encompasses the following categories: nouns > adjectives/adverbs > numerals > verbs/interjections. ${ }^{15}$

In DLGenR, we examine the "authenticity" of the borrowings as a part of the speakers' vocabulary by distinguishing between loanwords, as "defined" lexemes shared by the speech community, and ad-hoc-formations based on Greek (or Latin) linguistic material. ${ }^{16}$ In the sections below, we attempt to demonstrate that even the most "clear-cut" distinction for borrowings in modern linguistic theory (cf. Haspelmath 2009), namely the dichotomy between "cultural" and "core" borrowings vs. code switching and ad-hoc-formations, allows us to elucidate several crucial differences within our material.

\subsubsection{Cultural \& core borrowings vs. code switching \& ad-hoc formations}

At first glance, cultural borrowings that designate a new concept coming from "outside", seem to involve the main class, to which Greek and Latin loanwords in Jewish Aramaic traditionally belong. The explanation for cultural loans, the so-called "loanwords by necessity", is - generally speaking straightforward and reflect the impact of technical innovations and the emergence of new cultural and social settings. The major areas for cultural borrowings in the Rabbinic literature encompass: (i) government and army; law and justice; taxation; occupations; (ii) realia; plants; food and beverages; storage; sailing; luxuries; lightning; writing; time; (iii) characteristics, sobriquet; poetry (cf. Shoval-

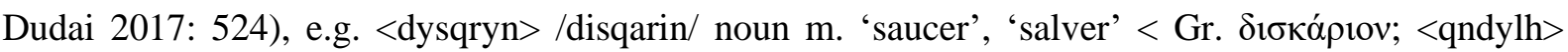
/qandelah/ noun f. 'candle [esp. of wax]', 'lamp', 'light' Lat. candela; <'yprkhy'> /eparkhia'/ < Gr. $\dot{\varepsilon} \pi \alpha \rho \chi i ́ \alpha$ etc.

The explanation with respect to the second category of loanwords (according to Haspelmath 2009), namely the "core borrowings", which "involve loanwords that duplicate or replace existing native words" (Haspelmath 2009: 48 following Myers-Scotton 2002 \& 2006) is more complex to recognize. And as the author contends: "Why should speakers use a word from another language if they have a perfectly good word for the same concept in their own language?". In many cases, the notion of "prestige" has been proposed as the main "trigger" for core borrowing, but in general this phenomenon is related to the fact that "[T] he way we talk (or write) is not only determined by the ideas we want to get across, but also by the impression we want to convey on others, and by the kind of social identity that we want to be associated with." (Haspelmath ibid.)

Another significant observation is that speakers often tend to use words from another language for already existing concepts in cases where bilingualism is involved, since even an ad hoc use of the other language would not negatively affect the communication. Of course, in historical texts it is even more difficult to distinguish between the cultural and the core borrowings given the fact that our material is scattered and - even more important - in most cases it is impossible to trace connotations and semantic

copying of syntactic, morphological or semantic patterns (e.g. word order patterns, case-marking patterns, semantic patterns such as kinship term systems)".

${ }^{14}$ For more information on Coptic see under https://www.geschkult.fu-berlin.de/en/e/ddglc (Dictionary and Database of Greek loanwords in Coptic)

${ }^{15}$ For a detailed discussion cf. Katsikadeli \& Slepoy (2020).

${ }^{16}$ Hoffmann's and Tichy's (1980) "authenticity" primarily refers to the differentiation between "native" and "borrowed" vocabulary, i.e. all loanwords should be considered "non-authentic" as far as the etymology of the lexicon of the specific language is concerned; here, we adapt this notion to our objectives and make use of sub-categories from the set of criteria pertaining to "authenticity". 
nuances or usage restrictions of quasi-synonyms in diachrony. Next to the examples for the Greek color terms 'black' and 'white' in Aramaic that could be explained as typical domain for borrowings in bilingual communities (see above under 3.2), a good example for a "prestige" loan is the adoption of the Greek word for 'property, estate', a frequent term since Herodotus and the Classical sources: <prwqwpy> /proqope/, <prwqpy>/proqope/ pl. <prwqop'wt>/proqopa'ot/ noun f. 'preferment; promotion; distinction' $\sim$ Gr. $\pi$ роко $\pi \eta^{17}$. The Classical and Hellenistic attestations encompass the following meanings for this word: 1. generally, 'progress; advance, proficiency" (also in LXX, Si.51.17; and the NT (Ep.Phil.1.12); 2. 'success, prosperity; 3. explicitly 'military promotion' (in Josephus, BJ6.2.6); 4. 'time process'; 5. 'progression of numbers' (as a mathematical term). In GenR we encounter a narrower range of meanings, namely 'preferment', initial as a 'military distinction' conferred by the king, i.e. in accordance with the semantics of 2. and 3. above:

In the following passage, the recipient of the 'preferment' is the earth (by metaphorical means):

(3) GenR 12,16 (I 113: 4,5)

"Earth and heaven (Gen 2,4). This may be compared to a legion, which was the first to proclaim the king. Said the king: 'Since this legion was the first to proclaim me king, I will give it a preferment < prwqwpy> which shall never be taken from it.' Even so said the Holy One, blessed be He: 'Because the earth was the first to fulfil My desire, I will give her a preferment <prwqwpy> which shall never be taken from her.' Hence it is written: Who didst established the earth upon its foundations, that is should not be moved for ever and ever (Ps 54,5)." (cf. Freedman / Simon I 99)

Further, a closer study of Greek loanwords in GenR, brings another distinctive feature into light, which refers to the contextual occurrence of these lexemes, i.e. a criterion on the text level: the "coreborrowings" are often used to reconstruct a Graeco-Roman cultural setting: in example (4), the aforementioned $<$ dyptr'> /diftera'/ Gr. $\delta i \varphi \theta \varepsilon \dot{\rho} \alpha$ '(prepared) hide', here in the sense of 'record book', co-occurs with other Greek terms in a 'nested usage' describing an architect's utensils ${ }^{18}$ :

(4) GenR 1,1 (I 2: 2)

"In human practice, when a mortal king builds a palace, he builds it not with his own skill but with the skill of an architect. The architect moreover does not build it out of his head, but he has

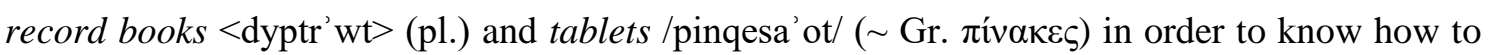
arrange the chambers and the wicket doors." (Cf. Freedman / Simon I 1) ${ }^{19}$

These mentions, which at first glance point at cultural borrowings, could in fact reflect the authors' intention for a "switch" into the Graeco-Roman world. Such frequently attested examples indicate the linguistic awareness of the authors/speakers concerning the origin of the lexemes, a fact that is not always the case with cultural borrowings, which fill up a gap in the lexicon for a specific technical or cultural innovation. Such examples demonstrate that it is crucial to take into account and differentiate the various contexts of occurrence for each loanword, i.e. its functional use in discourse.

In order to capture the nature of this specific use of the Greek loanwords, we introduce another significant distinction connected with borrowings, which has been neglected in the respective scholarship, namely the existence of code-switching phenomena. Language contact research employs the term code-switching, which at an abstract, theoretical level, can be traced according to the assumption: "If the word is part of the mental lexicon of the speaker, it is a loanword, otherwise it is a single-word switch" (Haspelmath 2009: 40).

\footnotetext{
${ }^{17}$ Cf. Krauss, LW II 487a; Cf. AC VI 449b; Levy IV 139a; Jastrow II 1221a. Pl. attested also in PesR 43.

${ }^{18}$ Gribetz \& Grossberg (2016:7) provide two examples concerning the "rich" usage of foreign -in this case Greek - vocabulary, which occur at the beginning of GenR: “...GenR employs a parable about a king in the context of the Roman Empire, no doubt drawing imperial allusions for its ancient audiences, and it uses an architectural analogy, perhaps gesturing to similar metaphors about the world's creation in classical and Hellenistic philosophy popular in the late antique east. The artisan-tools that God as the divine architect employs by looking into the Torah are precisely those employed by an artisan of the eastern Roman Empire of the fifth century."

19 = Yalq 2 [2a: 54] (דפטראות); Yalq Prov 942 [490b: 41] (דיפתראות)
}

Selected Papers from the workshop „Digital Lexis, and Beyond”, 45th Austrian Linguistics Conference, Dec. 2019 
But is it possible to distinguish the "proper" loanwords from code-switches in historical corpora, when this task proves to be difficult even for modern languages? Indeed, a preliminary comparison with the Greek loanwords in the Mishnah (Judaism's major religious text from the $3^{\text {rd }} \mathrm{c}$. CE) reveals that codeswitching is genre specific. The material there mainly concerns cultural borrowings, a fact which reflects the practice of a rather conservative Mishnaic Hebrew and not the Aramaic dialect of a later period and of a different social setting, while the loanwords in GenR seem to have entered Aramaic also through every-day situations. Of course, the main tool we have at our disposal for the recognition of codeswitching is the contextual occurrence. In GenR we find a passage, which convincingly demonstrates the intentional switch into "other" social groups or customs: The general overview in GenR 23,3 referring to the Biblical figure of Lamech is that the members of his family are connected to a "word field" associated with "low morality" and "praising idolatry" through singing and playing music instruments, as in a passage about Jubal, Lamech's son, where we encounter the Aramaic forms $<$ 'drblyn $>$ /'idravlin/, <'drblwn> /'idravlon/ noun m., pl. 'water-organ' or 'water-organ-players' Gr.

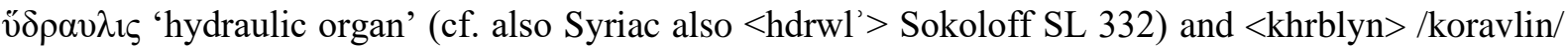

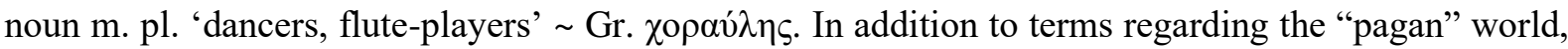
in GenR, we often deal with cases of intended usage of borrowed vocabulary for ad-hoc folketymologies (or more precisely, paretymologies), e.g.:

(5) GenR 81, 5

"R. Samuel b. Nahman said: This is Greek, in which allon means another, indicating that while he was mourning for Deborah, tidings reached him that his mother had died. Hence it is written, And God appeared unto Jacob again ... and blessed him (Gen 35, 9)." (transl. Freedman/Simon) Likewise, in the next example /'alio/ is explained as part of the same lexeme:

(6) GenR 60,15 (II 656 1)

"Behold, this [ha-la-zeh] dreamer cometh" (Gen 37,19). The Rabbis said: This is his guardian

[angel]; ha-la-zeh - this is another (<'lyw $>$ /'alio/) one." ${ }^{20}$

These instances of word-play and paretymology in (5) and (6) comply with a fundamental observation in language contact research: while borrowings are "established" lexemes of a language system by definition, "code-switching, by contrast, is defined as the use of an element from another language in speech 'for the nonce', so 'nonce-borrowings' should be called code-switches" (Haspelmath 2009: 41, following further lit.).

In this context we want to point out that examples of paretymology and "nonce-borrowings" might constitute cases which are primarily relevant for the text's philological interpretation, nevertheless the implication for the evidence on the "cognitive", linguistic level are equally important: they provide evidence for a higher level of the speaker's linguistic competence in Greek than the one usually assumed for the Jewish community of that time.

\subsection{Phonological and morphological adaptation}

As far as the etymological stage of tracing the word meaning is concerned, the Rabbinic scholars have and the Jewish classical philologists have achieved an immense contribution: the criteria of philological semantic interpretation and thematic environment have been meticulously served through the ages. As we discussed above, the treatment of Greek loanwords and of their entries lack the features of usage differentiation and of semantic shift tracing, which - of course - became mainstream linguistic domains only decades after the compilation of the relevant dictionaries. In the examples under 3.4.1, we already encountered usage related domains (e.g. Gr. $\chi о \rho \alpha v ́ \lambda \eta \varsigma, ~ v \delta \delta \rho \alpha v \lambda ı)$ as well as semantic narrowing and

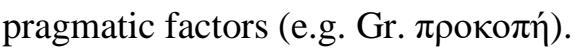

\footnotetext{
${ }^{20}$ Lat. alius could be another possible source.; = Yalq 109 (32b: 40-41) (אלון)
} 
In this unit we move on to the next category, namely to "tentative reconstruction" of the loanwords, according to criteria involving the phonological adaptation, gender assignment and plural marking that were neglected likewise in the past. Apart from the fact that the integration of loanwords is a phenomenon where a multitude of factors seem to play a role per se, an additional difficulty has to do with the writing system of Hebrew/Aramaic, which makes the recognition and etymology of loanwords even more complex as in other languages transmitted in alphabets including graphematic representations and distinctions for (all) vowels.

Let us illustrate the above mentioned factors and their interplay in the following example:

For the Aramaic form <'ndrwlwmwsy'>/androlomosiya'/, <'ndrwmwsyyh > /andromosiyyah/ noun f., we chose the explanation with an attested Hellenistic Greek lexeme $\alpha \dot{\alpha} \delta \rho \circ \lambda \eta(\mu) \psi i ́ \alpha$ as a source lexeme (following Jastrow I 81b), a compound < $\alpha \nu \delta \rho o-~ ' m a n '+-\lambda \eta(\mu) \psi i \alpha$ 'seizure', thus the meaning 'seizure of men':

(7) GenR 26,5 [I 248: 7]

R. Simlai said: Wherever you find harlotry, a plague of humans comes into the world and kills both good and bad. ${ }^{21}$

(8) 32,8 [I 295: 10]

And the Lord shut him in $(\mathrm{Gen} 7,14)$. R. Lewi said: This may be compared to a king who decreed a general execution in a country, but took his friend, immured him in prison, and set his seal upon him. Even so, And the Lord shut him in. (Freedman / Simon I 254)

Admittedly, one has to reconstruct several phonological steps in Aramaic, in order to secure the linkage with the Greek counterpart: the Rabbinic form might be explained by a secondary vowel insertion between the nasal $m$ and the sibilant (after the loss of p): */androl(e)mpsiya'/ > */androl(e)msia'/ > /androlomosiya' $\%$ For this word other suggestions have been made: Krauss, LW I 124 explained as Gr.

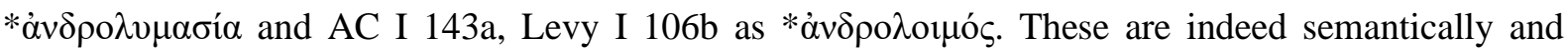
phonologically plausible proposals, but they are not witnessed in the Greek corpora. Therefore, since we deal with a "stalemate" situation for a dubious case, we include these proposals in our entry, but according to a "proposal ranking" (as suggested by Hoffmann \& Tichy 1980). For <'ndrwlwmwsy'> /androlomosiya'/ we propose and analyse one solution $(\dot{\alpha} v \delta \rho o \lambda \eta(\mu) \psi(i \alpha)$, but mention other possibilities at the end of the entry, which are accompanied by appropriate arguments against their "higher ranking". Finally, while most of the problematic cases involve meticulous consideration of philological, semantic and phonological investigation, on the morphological level, the DLGenR pays special attention to the most striking category in this group of loanwords, which are the linguistic innovations, whether they refer to "neologisms" or novel patterns in word-formation, esp. involving compounds, a.o. <'ntyqysr>

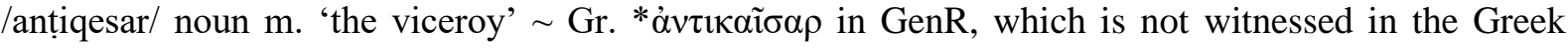

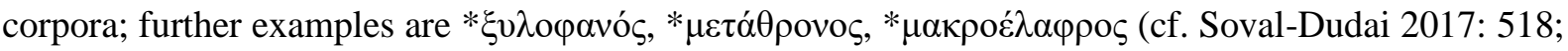
524 for more cases of compounds).

\section{Checking etymologies II: deep encoding}

Bringing together the above stages of our etymological survey, in the course of the DLGenR compilation as a digital born dictionary we dealt with a large variety of features and their specialized categorization, the precise annotation of which is crucial for further research and the interoperability of heterogeneously encoded lexical resources, for instance, the alignment of similar findings that concern Greek loanwords in other Rabbinic texts or cultural and linguistic areas (Egypt, Asia Minor etc). The DLGenR encodes its lexical entries according to the specifications and recommendations of TEI Lex-0 within the TEI Guidelines. The merits of this particular TEI schema customization as a set of community-based

\footnotetext{
${ }^{21}=$ ySoṭ 1,5 [909: 31] (אנדרולמוסיה); (אנדרולומוסיא); LevR (Margaliot) Ahare 23,9 [539: 4] (אנדרולומוסיא); Yalq 43 [12d: 17] (אנדרלמוסיא)
}

Selected Papers from the workshop „Digital Lexis, and Beyond”, 45 th Austrian Linguistics Conference, Dec. 2019 
recommendations, have been already demonstrated by various projects, i.a. the VICAV dictionaries ${ }^{22}$, therefore, in what follows, we limit our presentation to the core entry elements regarding borrowing and highlight the encoding that corresponds to some "special cases", which at the same time represent the novel approaches and insights of this dictionary. In particular, we follow the recommendations for etymological encoding with special attention to the subcategories "borrowing" and "compounding", as proposed by Bowers \& Romary (2017) and adapt them to the needs of our project. In detail:

a) The basic concepts (i.e. the microstructure) of a DLGenR entry pertaining to a loanword are, as expected:

-the borrowing language, which in the majority of cases is Greek, and less frequently Latin (or, as described above, Latinate)

-the source language is Jewish (Palestinian) Aramaic

-the borrowed form (in Hebrew orthography + transcription alongside a "traditional Rabbinic" pronunciation)

-the source forms are Greek or/and Latin (orthography in original characters);

-the semantic profile/metalinguistic concept

(cf. Bowers \& Romary 2017: 81)

Further, the encoding of all these features combined with the borrowing phenomena we discussed in previous sections is plotted in the model in Fig. 1.

As far as borrowing mechanisms and etymology are concerned, our lexicographical decisions imply the following specifications for our loanword encoding in TEI-Lex-0:

a) For examples like $\mu \varepsilon \lambda \alpha{ }^{\prime} v 1(0) v$ (see 3.2. above), which has been verified as a "genuine" post-Classical Greek loanword, we link the respective lemma not to the LSJ-entries $\mu \varepsilon \dot{\varepsilon} \lambda \alpha \nu$ or $\mu \varepsilon \lambda \dot{\alpha} v \eta$, but to the morphologically and chronologically appropriate Greek attestation from the Lexikon zur Byzantinischen Gräzität (LBG).

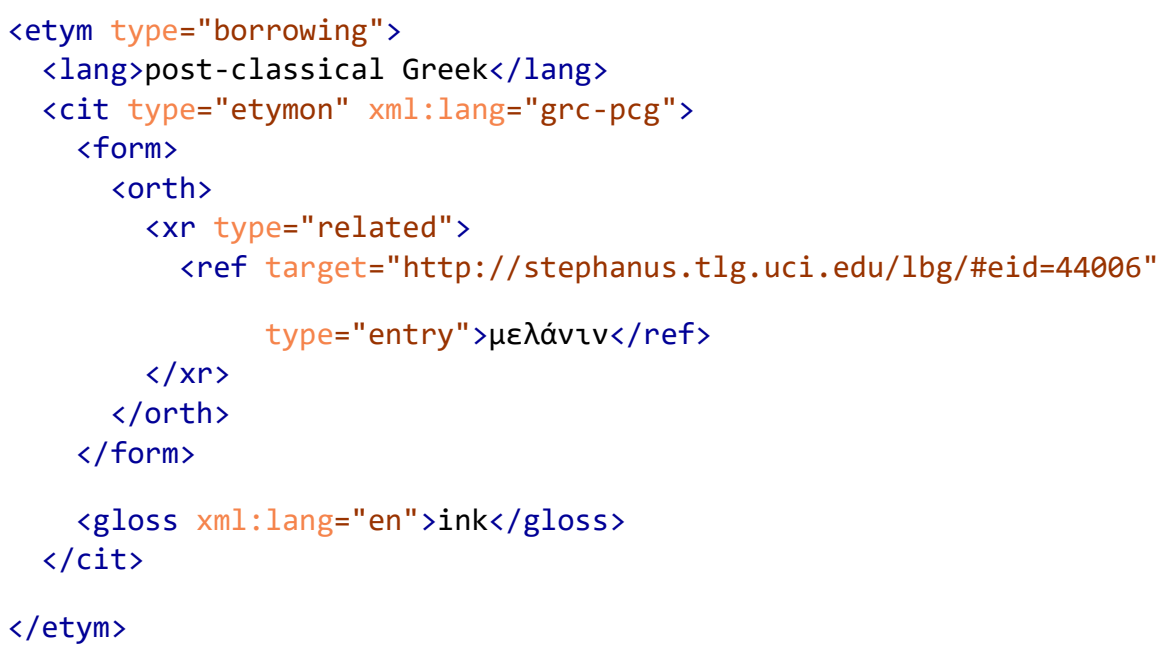

Again, we wish to point out that this task is not an "automatic" linkage, but it regards only cases where the philological and etymological investigation leads to the conclusion that both the Greek lexeme and his borrowed counterpart in Aramaic share the same linguistic properties, especially in terms of their semantics and/or morphophonology. In turn, if the semantics of the item in the source language differ from that of the borrowing language, the original can be included in the element $\langle$ gloss $\rangle$ (following TEI Lex-0). Further, in order to highlight the chronological differences within the attestation period of the Greek lemmas we distinguish between the language codes grc (classical Greek), grc-pcl (postClassical Greek) and $e l$ for Modern Greek, e.g. 〈cit type="etymon" xml: lang="grc-pcg">

\footnotetext{
${ }^{22}$ See Moerth \& Schopper in this volume.
} 


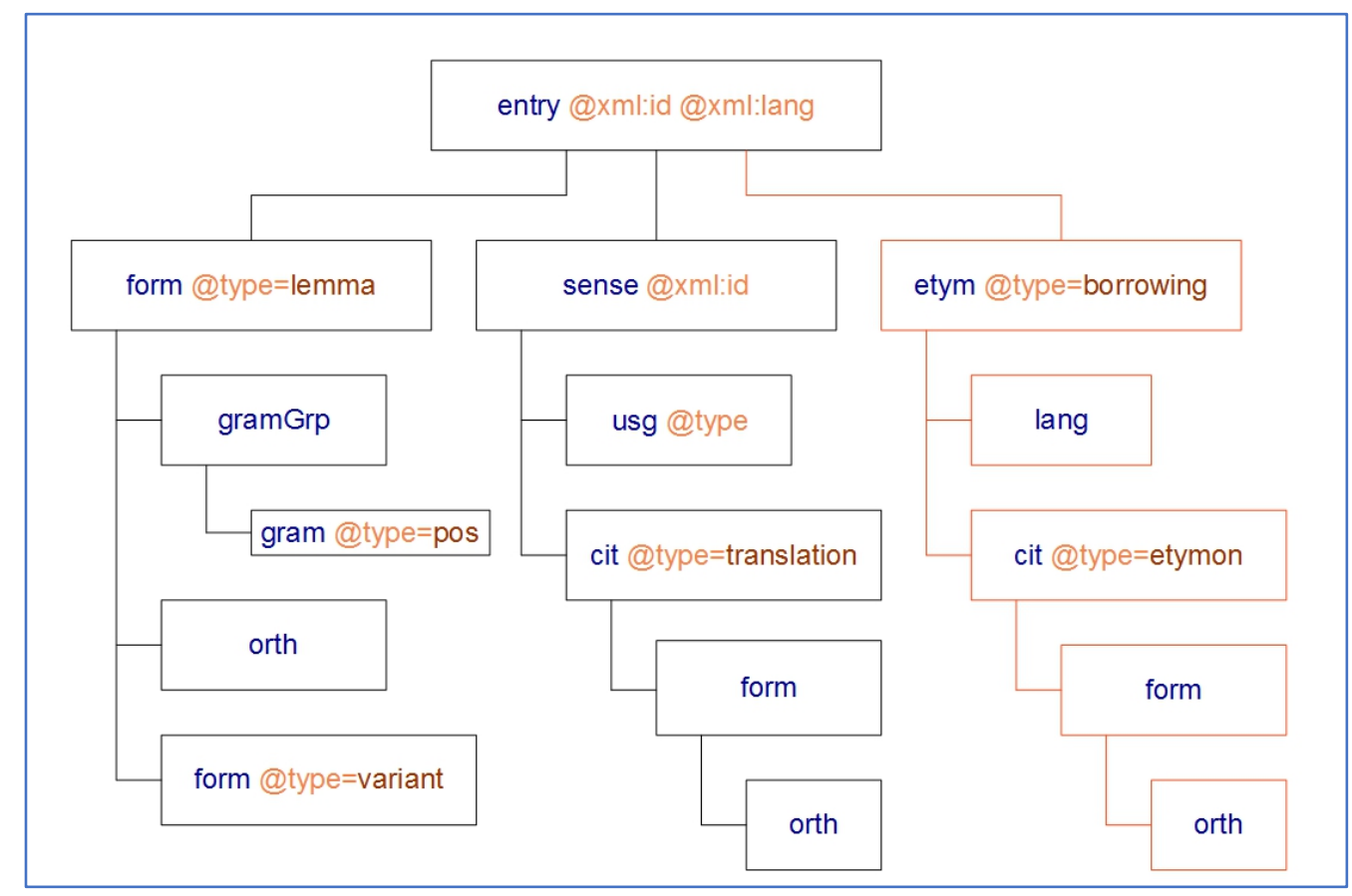

Figure 1: Overall model for etymological borrowing according to Bowers \& Romary (2017: 82)

Likewise, for the areal distribution beyond the Hebrew/Aramaic tradition, we offer attested forms in Coptic and Syriac, within the usage section under 'sense' <usg type="geographic" / >

b) Another major concern in DLGenR is - as expected - the encoding of the orthographic adaptation of the borrowed Greek lemmas. The presentation of all orthographic varieties regards the occurrences in the GenR (major) manuscripts and editions only. This practice has been followed due to the plethora of Aramaic transliterations for one single word in our corpus, but - above all - in order to examine each loanword in its own right, i.e. within one text and region, before moving on to over-generalizations about the usage of a specific lexeme in the entire Rabbinic corpus. Therefore, we offer the orthographic variants for the Theodor-Albeck edition of GenR as well as for the Vatican Mss $30 \& 60$, Oxford Mss Ox1: Bodl., Opp. Add. fol. 3 \& Ox2: Bodl., Opp. Add. fol. 51 and the Venice (1545) and Konstantinople (1512) editions respectively. For the variation in different manuscripts of the Aramaic counterparts of Gr. $\dot{\alpha} v \delta \rho \circ \lambda \eta \psi i ́ \alpha$, we encode as follows:

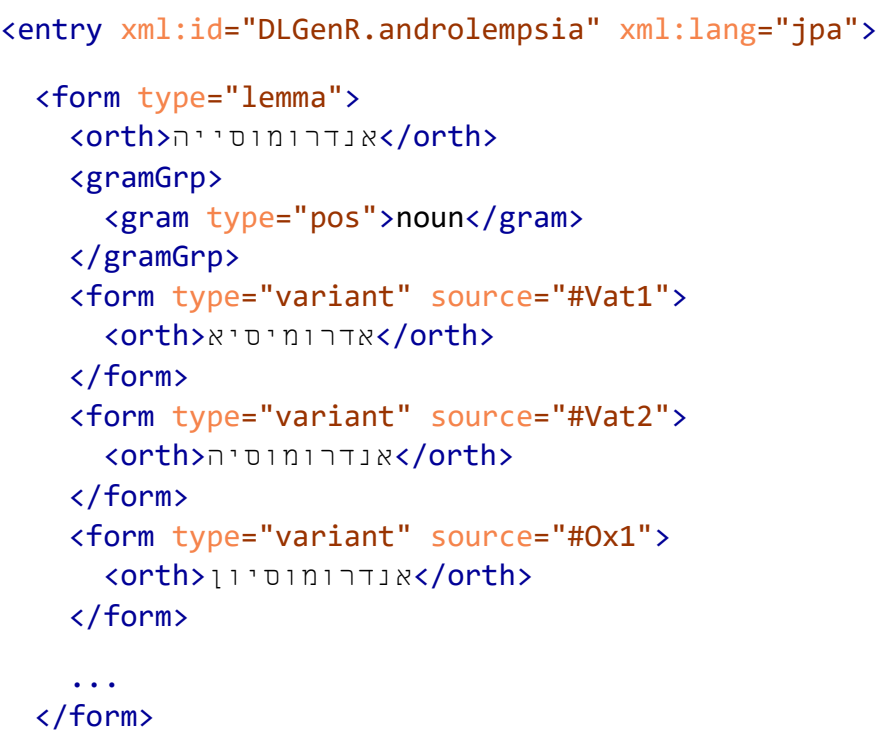




\section{$</$ entry>}

c) The transliteration of Aramaic in DLGenR follows the FJB 2 (1974) guidelines, a mainstream practice in Jewish studies. The pronunciation that we provide does not always comply with a "scientific" historical reconstruction, but instead we opt for the so-called Rabbinic Schulausprache, in order to facilitate the usability of the dictionary also by non-Semitists. The phonological reconstruction of unattested or ambiguously attested vowels in the JPA transmission is beyond the scope of this stage of compilation, nevertheless, this feature could be added in the course of future projects.

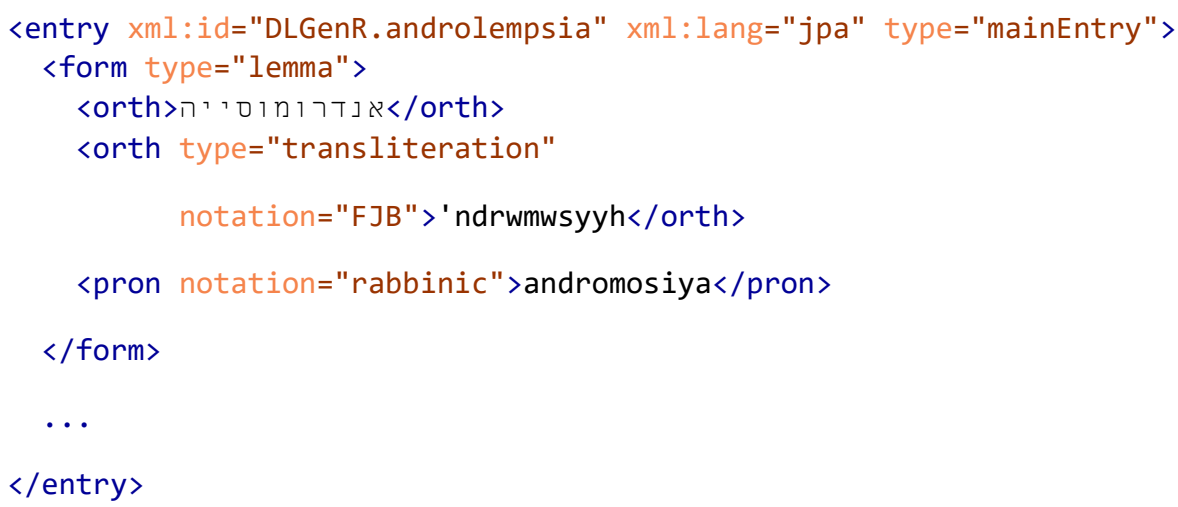

d) Of course, there is always information about whether the lexical item is a hapax legomenon or it is attested elsewhere in the Rabbinic literature, but without providing detailed data that pertain to other sources as a default feature; this regards only selected cases, where this extra reference is indispensable for further linguistic argumentation. This information is encoded within <usg type="frequency" /> in the "usage section" together with the <usg type="domain"/>, which also encompasses "mainstram" lexicographical labels such as technical, medical terms etc. Further, the DLGenR encoding also profits from another new feature of TEI Lex-0, namely the detailed differentiation of usage labels (cf. Salgado et al. 2019):

The distinction that we introduced in 3.4.1 regarding cultural, core loans and code-switching is encoded under the socioCultural label TEI Lex-0, which distinguishes a "diaphasic marking":

<usg type="sociocultural"/>

Another suitable markup for the DLGenR-entry is the normativity label, i.e. "a marker which identifies the use of a given lexical unit which is in some aspect considered to be non-standard or incorrect". In DLGenR this label serves the distinction between a "standard" Greek lexeme and ad-hoc usage or formation (see also the nonce-borrowings under 3.4.1 above)

<usg type="normativity"/>

Finally, the meaningType-label, defined as "a marker which identifies a semantic extension of the sense of a given lexical unit" (TEI Lex-0 s.v.) is utilized in the DLGenR within a broader range, i.e. also encompassing the values of semantic "narrowing" and "lexicalization":

<usg type="meaningType"/>

e) The morphological modelling of the borrowings encompasses not only their part-of-speech, gender and number classification, but also the respective information about the lexeme in the target language: gender assignment and number specialization (occurrence in plural only) are crucial features in the study of borrowing mechanisms:

$\langle$ gramGrp>

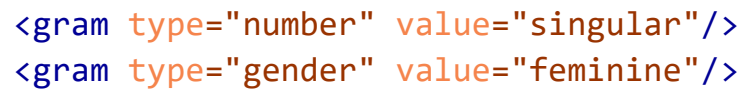


f) As we mentioned in 3.5. above, we pay special attention to cases of compounding. As a first step, we check all the basic steps for modelling compounds and compounding, which - as summarized by Bowers \& Romary (2017: 112) - include: a) the delimitation between the components; b) the grammatical profiles of the components; c) the meanings (senses) of the components; d) the semantic domain of the components. The implications for the DLGenR compound encoding are the following three categories under the etymology section:

1) If the word is borrowed as such from Greek, then we link the Greek form as a "single lexeme" to an external source, without segmenting the compound members; here for instance, we encode the relation of an Aramaic form to its Greek counterpart $\alpha \sigma \tau \rho o \lambda o \gamma i ́ \alpha$ 'astrology':

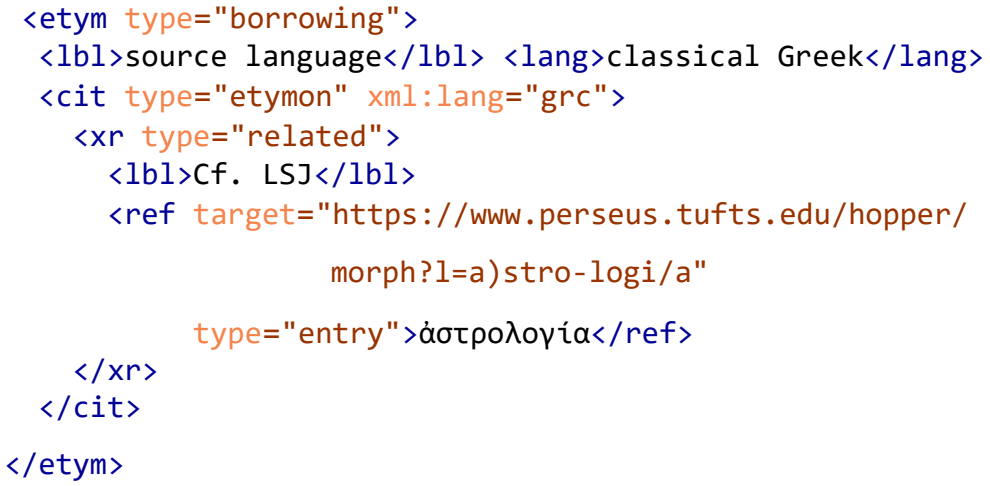

Where needed, we chose the more thorough method of encoding the individual members of a compound form that is directly borrowed from Greek. Thus, our analysis in such cases requires the combination of borrowing and compounding markups under within the etymology section:

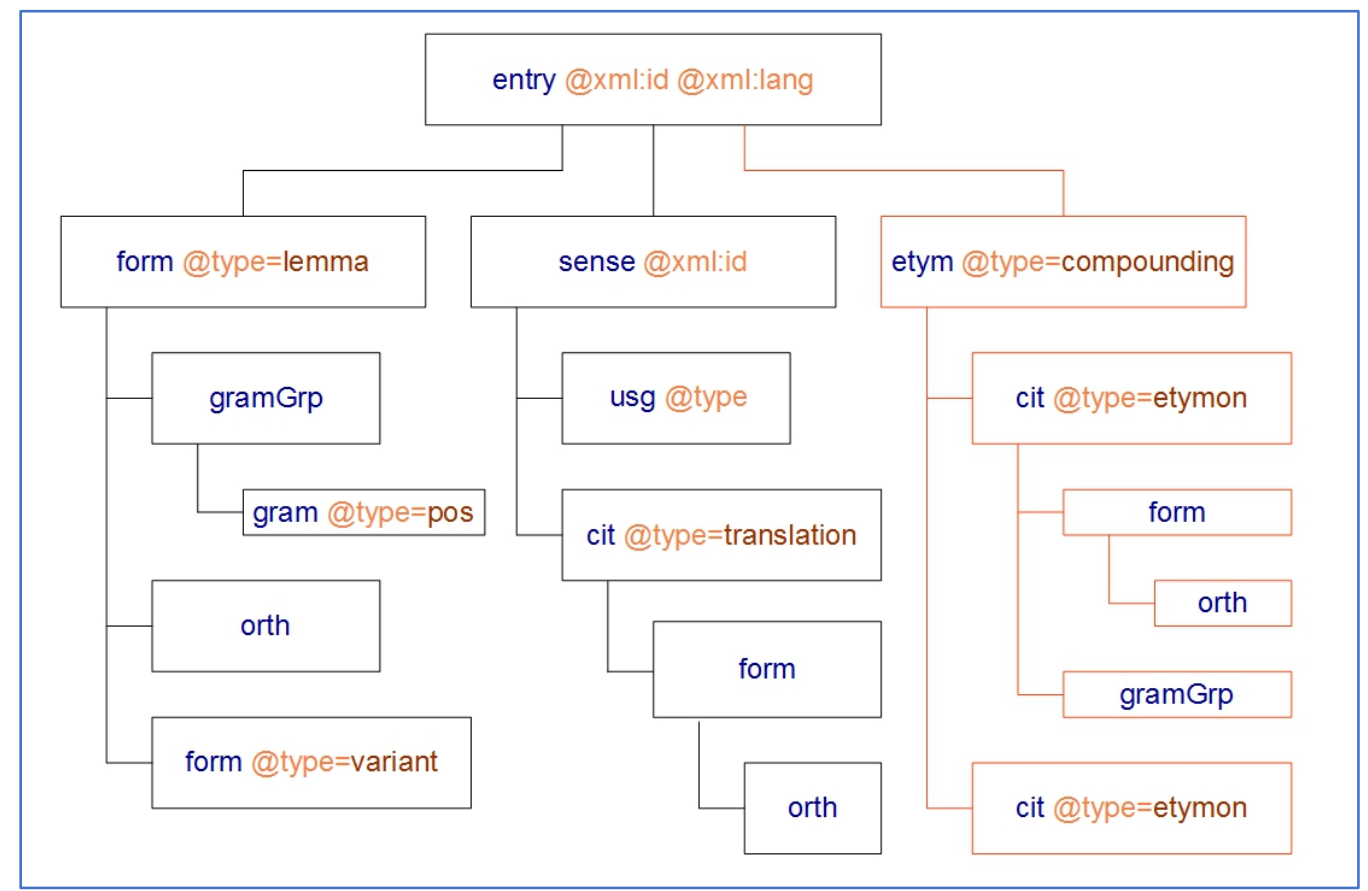

Figure 2: Overall model for compounding according to Bowers \&Romary (2017: 118)

b) In the case of $<$ 'ndrwlwmwsy'> /androlomosiya' $<$ Gr. $\alpha v \delta \rho \circ \lambda \eta(\mu) \psi i$, we deal with a case, the etymology of which combines "borrowing" and "compounding" markups, thus:

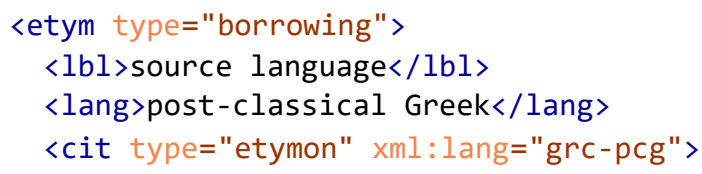




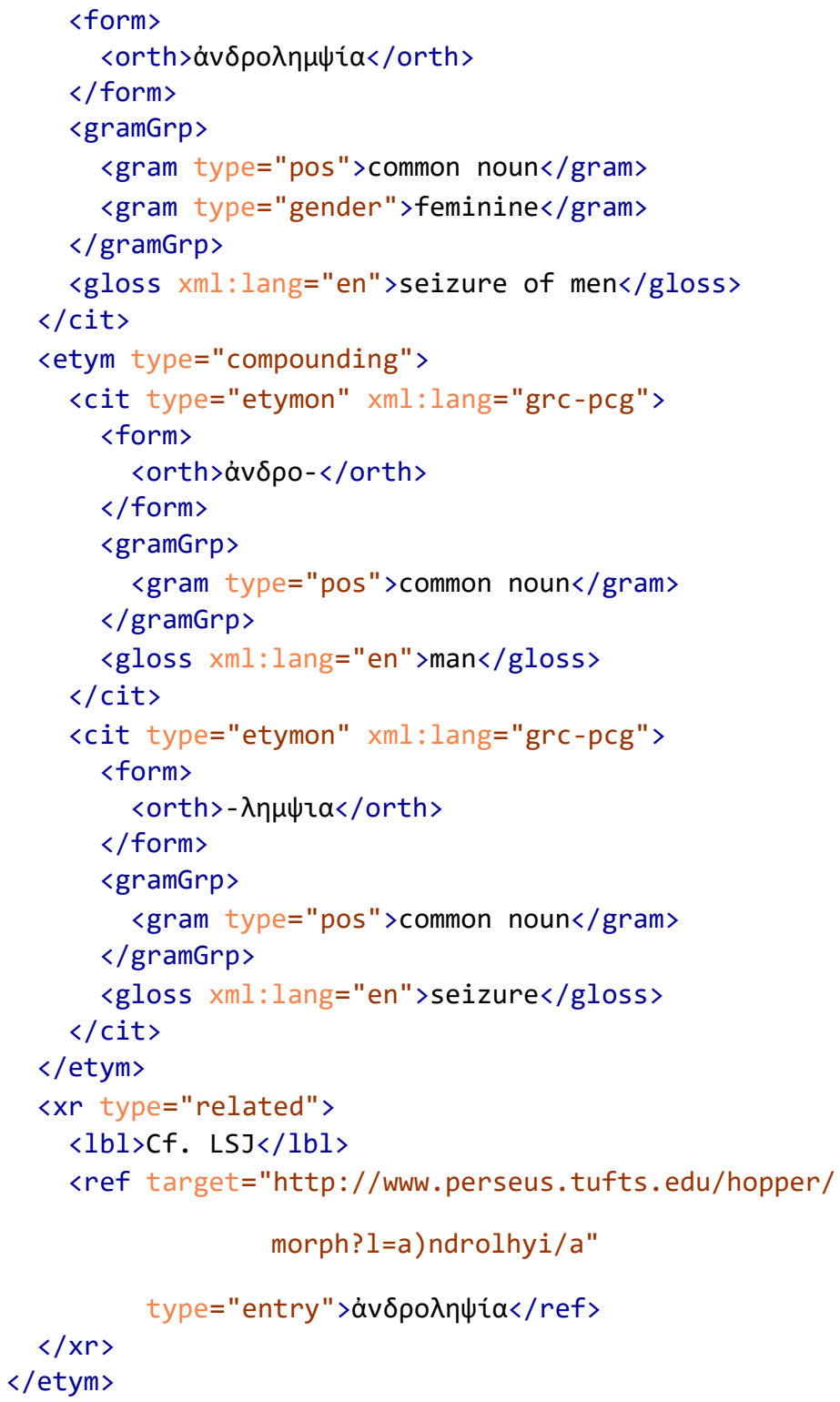

3) The third category involves cases, where we deal with a novel word formation in JPA, such as the example * $\dot{\alpha} v \tau \iota \kappa \alpha i ̃ \sigma \alpha \rho$ from GenR, a hybrid Graeco-Latin title referring to an oriental 'viceroy', which encounters in the Rabbinic literature only. Here, we encode the relevant information on the type of the compound (endocentric, exocentric, coordinative). Since this word formation should be regarded as the outcome of "synchronic" compounding by the speakers of that time, we consider these word formations "indigenous" compounds and not borrowed forms:

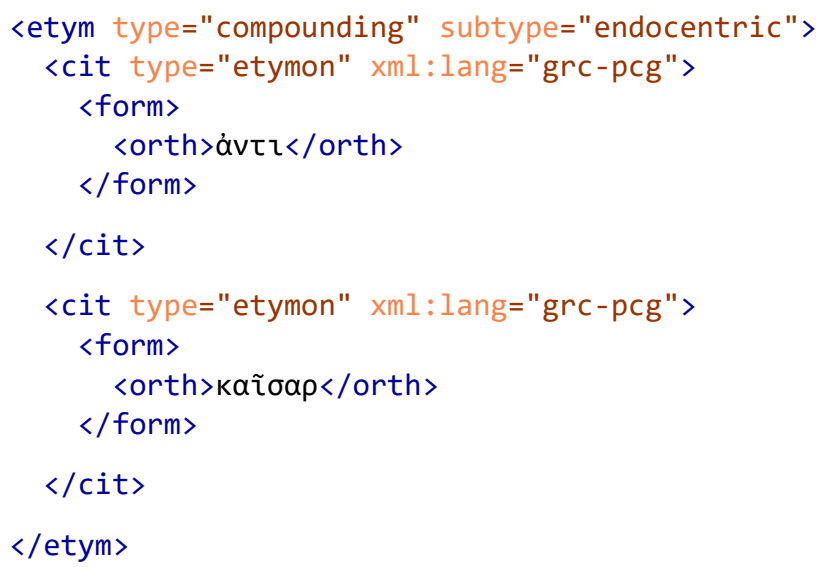




\section{Summary and outlook}

Our knowledge of Greek (and Latin) has increased with the further discoveries and publications of papyrological, epigraphic and vulgar sources with a special stress on dialectology as well as the patristic and Early Byzantine literature (and their lexicography). As far as the Greek borrowings are concerned, until the entire Greek material in Aramaic is investigated anew, we must limit ourselves to raising and discussing a number of issues, rather than endorse specific explanations. Nevertheless, the ongoing collection of data reveals a wider range of unexplored facets of this evidence, which has fallen into oblivion for many decades:

Although the bulk of Greek lexemes in Hebrew/Aramaic involves loanwords - according to the "traditional" definition of the term - we may definitely benefit from the consideration of a range of other borrowing phenomena that are more or less closely related to loanwords. Beside the subcategorization of the loanwords in cultural and core borrowings, a critical assessment of the Greek lexemes alongside with modern linguistic theory enables us to discover more about these lexical items and their specific function in discourse as well as to detect instances of code-switching (see chapter 3.4.1). At least for these the authors of GenR, the presence of code-switching helps us to understand their usage of loanwords based on a certain grade of bilingualism and not a "mere" diglossia.

b) Our recently accumulated knowledge on Greek data and historical linguistics, in turn, helps us to correct, revise and improve lexicographical entries and scholarly translations. According to the examples presented in the previous passages, in Table 1 below, we summarize the following six domains and their subdivisions as adapted from Hoffmann \& Tichy (1980) regarding the criteria according to which the DLGenR entries should be compiled:

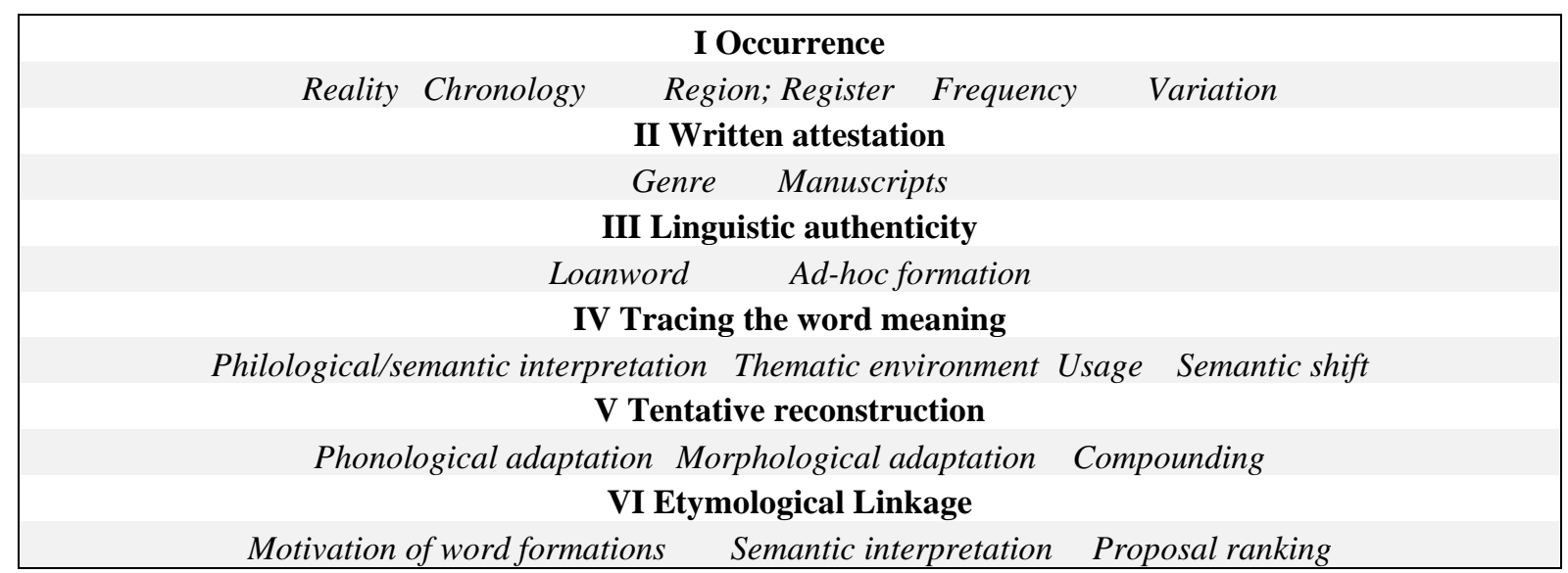

Table 1: Check list for the etymology of borrowings in GenR (adapted from Hoffmann \& Tichy 1980)

c) The inclusion of chronological, textual, regional as well as refined phonological and morphological criteria for the classification of borrowings entails in many cases implications for the investigation and lexicography of post-Classical and Byzantine Greek. In addition, the separate treatment for the so-called "re-borrowings" or "areal roots" 23 , such as $\delta i \varphi \theta \dot{\varepsilon} \rho \alpha$ in 3.2. above, must likewise be reconsidered. Again, the most important prerequisite for such classifications is the detailed study of the chronology of various borrowing strata according to linguistic and historical data from the Eastern Mediterranean, which concern cultural interactions that took place much earlier than the Graeco-Roman times. Finally, from the lexicographical point of view, a further and much more ambitious project would be the collection of

\footnotetext{
${ }^{23}$ This term refers to -in most cases- very archaic lexemes, which appear in languages from a number of different families in a particular area (cf. Awagana \&Wolff 2009).
} 
loan translations and loan creations in the linguistic area of the Eastern Mediterranean. The extraction and visualization (e.g. mapping of geographical lexical distribution) of all this extra information can be ensured only by the appropriate annotation and interoperability of existing or planned digital dictionaries and text collections. This, in turn, requires the constant enrichment and improvement of expandable and sustainable models for general and etymological markups, such as the TEI Lex-0, in digital (historical) dictionaries.

\section{Bibliography}

Awagana A. and H. E. Wolff, with D. Löhr. 2019. Loanwords in Hausa, a Chadic language in West Africa. In M. Haspelmath, \& U. Tadmor (eds.), Loanwords in the World's Languages. Berlin etc.142-165.

Bowers, Jack \& Laurent Romary. 2017. Deep Encoding of Etymological Information in TEI. Journal of the Text Encoding Initiative, 10, Selected Papers from the 2015 TEI Conference, https://doi.org/10.4000/jtei.1643

Dalman G. 1905 [1989]. Grammatik des jüdisch-palästinischen Aramäisch. Darmstadt.

Freedman H. \& Maurice Simon (eds). 1890 [31961]. Midrash Rabbah: Translated into English, 10 vols., London. Gribetz, V \& David M. Grossberg. 2016. Introduction: Genesis Rabbah, A Great Beginning. In S. K. Gribetz, D. M. Grossberg, M. Himmelfarb \& P. Schäfer (eds.), Genesis Rabbah in Text and Context, Tübingen, 1-21.

Haspelmath, M. 2009. Lexical borrowing: Concepts and issues. In M. Haspelmath \& U. Tadmor (eds.) Loanwords in the World's Languages. Berlin, 35-54.

Heijmans, Sh. 2013. Greek and Latin loanwords in Mishnaic Hebrew. Lexicon and phonology [in Heb.]. Tel Aviv University $\mathrm{PhD}$ thesis.

Hoffmann K. \& E. Tichy. 1980. „Checkliste“ zur Aufstellung bzw. Beurteilung etymologischer Deutungen. In M. Mayrhofer, Zur Gestaltung des etymologischen Wörterbuchs einer ,, Großcorpussprache“, Wien.

Janse, M. 2007. The Greek of the New Testament. In: A.-F. Christidis, (ed.), A History of Ancient Greek: From the Beginnings to Late Antiquity. Cambridge, 646-653.

Jastrow, M. 1903. A Dictionary of the Targumim, the Talmud Babli and Yerushalmi, and the Midrashic literature. London - New York.

Katsikadeli, Ch. (fc.). Language contact and linguistic competence in Graeco-Roman Palestine: Evidence from the Greek loanwords in the Midrash Genesis Rabbah. In Tagungsbeiträge: 19. Grazer Althistorische Adventgespräche, International Symposium: "The Aegean Interface: The Eastern Mediterranean - Ancient Meeting Place of Cultures”, Universität Graz, 12.-13. Dez. 2019.

Katsikadeli C. \& Vladislav Slepoy. 2020: Greek loanwords in post-Biblical Hebrew/Aramaic: some case studies from the midrash Genesis Rabbah. In Commentationes Humanarum Litterarum, 139, 111-132.

Krauss, S. 1898-1899. Griechische und lateinische Lehnwörter im Talmud, Midrasch und Targum, vols. 1\&2 Berlin.

Lewy, J. 1924. Wörterbuch über die Talmudim und Midraschim, vols. i-iv, Berlin, (Ndr. Darmstadt, 1963).

Lieberman S. 1965. Greek in Jewish Palestine, New York.

LSJ = Liddell, Henry G. Robert Scott, Henry S. Jones. 1996. A Greek-English Lexicon, rev. H. Stuart Jones and R. Mc Kenzie, Oxford.

Salgado, A., Costa, R. \& Tasovac, T. Improving the consistency of usage labelling in dictionaries with TEI Lex0. Lexicography ASIALEX 6, 133-156 (2019). https://doi.org/10.1007/s40607-019-00061-x

Shoval-Dudai, N. 2006. The integration of Greek and Latin loanwords in Post-Biblical Hebrew. In Scripta Classica Israelica, vol. 34, 215-225.

Shoval-Dudai, N. 2017. Ancient Greek in Ancient Hebrew. Unattested Greek loanwords in Post-Biblical Hebrew. In Ch. Tzitzilis, G. Papanastassiou (eds.), Greek Etymology, Thessaloniki, 495-512.

Shoval-Dudai, N. (fc.) A Glossary of Greek and Latin Loanwords in Classical Hebrew (in Hebrew), Academy of the Hebrew language.

Smelik, W.F. 2012. The languages of Roman Palestine. In Catherine Hezser (ed.), Jewish Daily Life in Roman Palestine, 1-14. Oxford: OUP.

DOI: 10.1093/oxfordhb/9780199216437.013.0008

Sokoloff, M. 22002. A Dictionary of Jewish Palestinian Aramaic of the Byzantine Period. Ramat Gan. Sperber, D. 1984. A Dictionary of Greek and Latin Legal terms in Rabbinic Literature. Jerusalem.

Sperber, D. 2012. Greek in Talmudic Palestine. Ramat Gan.

Theodor, Ch. \& J. Albeck, 1912-1929. Bereshit Rabbah. (six parts). Berlin. 